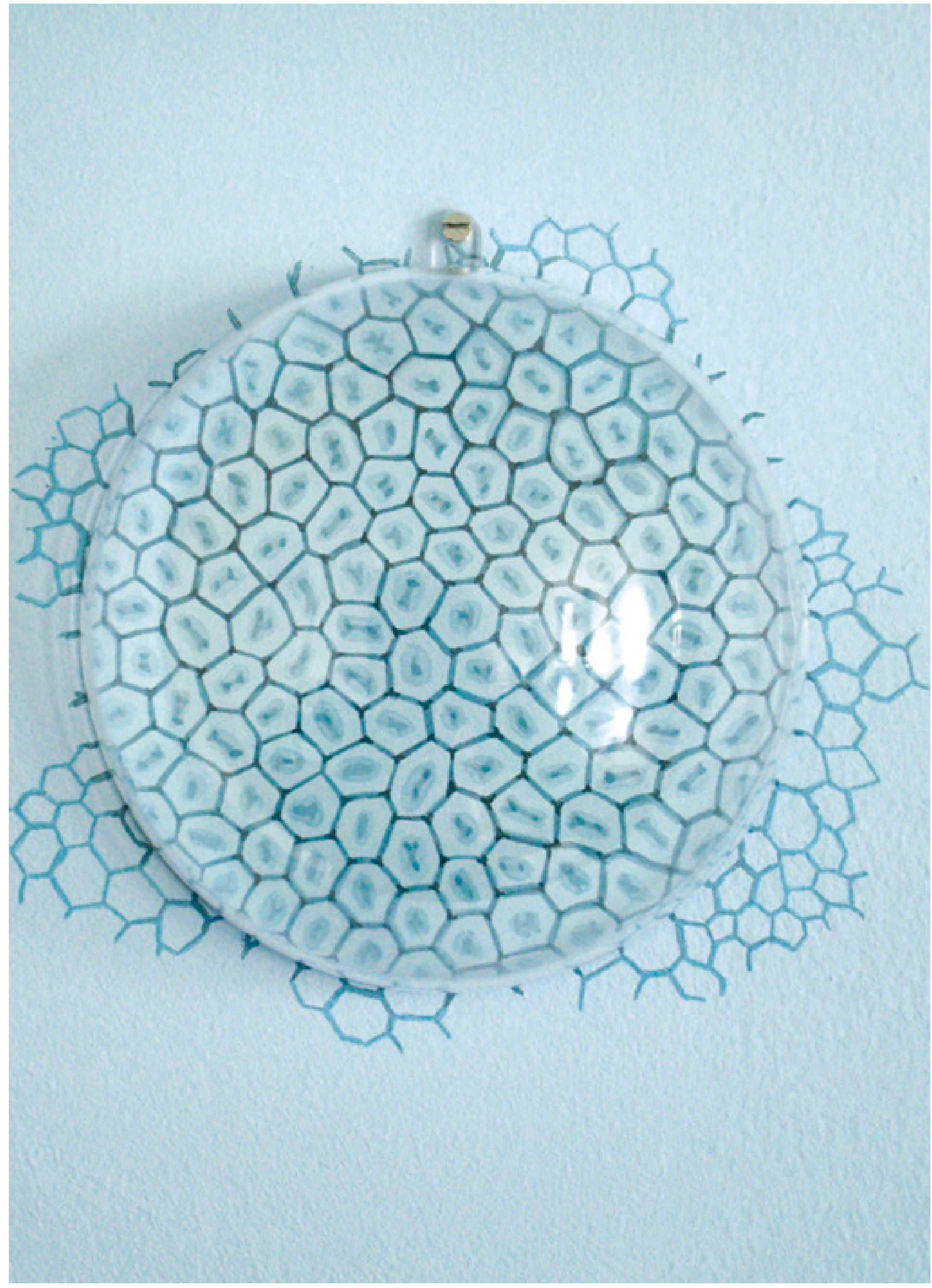




\title{
DARWIN I LA MILLORA GENĖTICA ANIMAL EVOLUCIÓ APLICADA A LA PRODUCCIÓ ANIMAL
}

\author{
Miguel Ángel Toro
}

Darwin va reflexionar sobre la potencialitat de la selecció natural comparant-la amb els efectes que han aconseguit els éssers humans amb la selecció artificial. En aquest treball s'analitza com, encara que la similitud entre ambdós tipus de selecció és visible, hi ha també importants diferències. També es presenten dos exemples d'aplicacions de la teoria evolutiva: la possible importància de la selecció sexual en la introducció de peixos transgènics i la selecció de caràcters socials en el context d'una millora genètica respectuosa amb el benestar animal.

Paraules clau: selecció artificial, selecció sexual, caràcters socials, benestar animal.

\section{SELECCIÓ NATURAL I SELECCIÓ ARTIFICIAL}

La diferenciació de les espècies domèstiques en varietats o races, amb diferents aptituds productives degudes a la pràctica continuada de selecció artificial, va suggerir a Darwin la idea que una força anàloga -la selecció natural- podria ser la causa de l'adaptació dels éssers vius als seus respectius medis. En les seues paraules: «Ben aviat vaig advertir que la selecció era la clau de l'èxit humà en la formació de races útils d'animals i plantes. Però durant algun temps va ser per a mi un misteri com se'n sortia la selecció sobre els organismes que viuen en condicions naturals. A l'octubre de 1838 [...], ben amatent per comprendre la importància de la lluita universal per l'existència [...], em va cridar immediatament l'atenció que, en aquelles circumstàncies, les variacions favorables tendirien a conservar-se i les desfavorables a desaparèixer. El resultat seria la formació de noves espècies. Aquí tenia, doncs, una teoria per treballar-hi.»

Encara que la similitud entre ambdós tipus de selecció és visible, hi ha també importants diferències. La selecció artificial és guiada per un seleccionador que imposa el criteri desitjat, siga producció de llet, calibre del fruit, etc., i manté aquest objectiu durant les generacions successives. En la selecció natural no hi ha un seleccionador, només hi ha individus que es reprodueixen diferencialment: uns deixen més fills i d'altres menys. Això depèn de les circumstàncies ambientals, que poden ser canviants en cada generació: temperatura, patògens, etc. El procés no té un objectiu ni una finalitat. En paraules de Darwin: «L'home només selecciona en el seu propi benefici, la naturalesa només en el de l'ésser de qui té cura.» En general els milloradors estan més interessats a predir els resultats que s'obtindran a curt i mitjà termini com a consequiència de les seues decisions respecte a la selecció i a la conservació, mentre que als biòlegs evolutius els interessa explicar i interpretar aquells canvis que ja s'han esdevingut, alguns dels quals tenen una llarga història (López-Fanjul et al., 2009). No obstant això, els mecanismes actuants són els mateixos: els canvis de les freqüències gèniques com a conseqüència de l'acció de forces selectives direccionals (d'artificials o de naturals) i de processos aleatoris (deriva genètica). El desconeixement dels mecanismes de l'herència biològica va imposar que la capacitat explicativa de la teoria darwinista s'exhaurira ràpidament i la seua vigència va quedar en suspens durant el denominat «eclipsi del darwinisme». En aquest interval, la millora dels atributs d'interès econòmic patia de la mateixa mancança teòrica i continuava basant-se en l'empirisme, que, en aquest cas, oferia millors resultats. No obstant això, a començament del segle Xx van co- 
MONOGRAFIC

La llum de l'evolució

mençar a incorporar-se a la millora tècniques derivades dels coneixements genètics del moment, adreçades a l'obtenció de línies amb un alt grau de consanguinitat per tal d'explotar el vigor híbrid que es manifestava en la progènie de determinats encreuaments entre elles. Aquest procediment, circumscrit en la pràctica als vegetals, no seria actualment aconsellable com a alternativa a la selecció artificial, però s'ha mantingut en algunes espècies, en particular la dacsa, per condicionaments del mercat.

R. A. Fisher i S. Wright van elaborar els models matemàtics que constitueixen el nucli teòric comú del neodarwinisme i de la millora genètica. Al primer es deuen la descripció genètica dels caràcters quantitatius i les prediccions teòriques de la resposta a la selecció en poblacions de cens elevat, i al segon, el tractament del canvi genètic per atzar i la seua influència sobre el resultat de la selecció quan el cens poblacional és reduiit. En les dues disciplines es va produir una aglutinació del coneixement biològic previ entorn d'aquests

\section{"LA RELACIÓ ENTRE MILLORA I EVOLUCIÓ HA ESTAT TAN ESTRETA QUE NO ÉS POSSIBLE DISTINGIR ENTRE ELS AVENÇOS DE LA TEORIA EVOLUTIVA QUE HAN CONTRIBUÏT ALS AVENÇOS DE LA} MILLORA GENĖTICA I VICEVERSA»

models, que va assolir el punt crític en els anys següents a la fi de la II Guerra Mundial i va conduir a les formulacions actualment vigents. Des de llavors l'intercanvi entre els avenços d'ambdues matèries ha estat continu. Per exemple, la teoria de límits a la selecció artificial es basa en els models estocàstics que descriuen el canvi de les freqüències gèniques per selecció natural en poblacions de cens finit, mentre que l'anàlisi de les forces selectives naturals que actuen indirectament sobre un conjunt d'atributs quantitatius es recolza en les tècniques multivariants utilitzades per predir la resposta de diversos caràcters sotmesos a selecció artificial simultània.

A finals dels anys seixanta del segle xx, més del $85 \%$ de les llavors de dacsa sembrades als EUA eren homozigots per a un gen que suprimeix el desenvolupament de les flors masculines, la qual cosa afavoreix la producció d'híbrids. No obstant això, una conseqüència no prevista de la presència d'aquest factor era l'augment de la susceptibilitat de les plantes a l'atac d'una estirp d'un fong, la qual cosa va ocasionar la pèrdua de més de mil milions de dòlars l'any 1970.

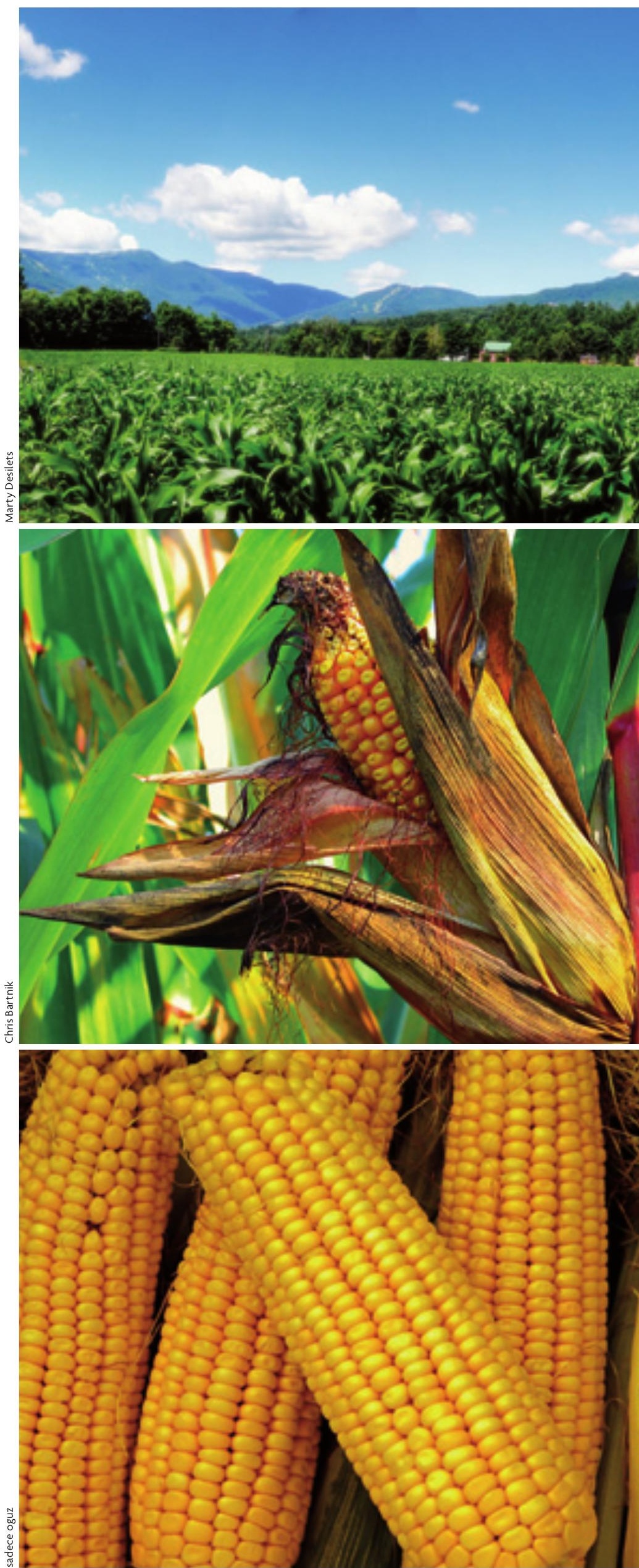




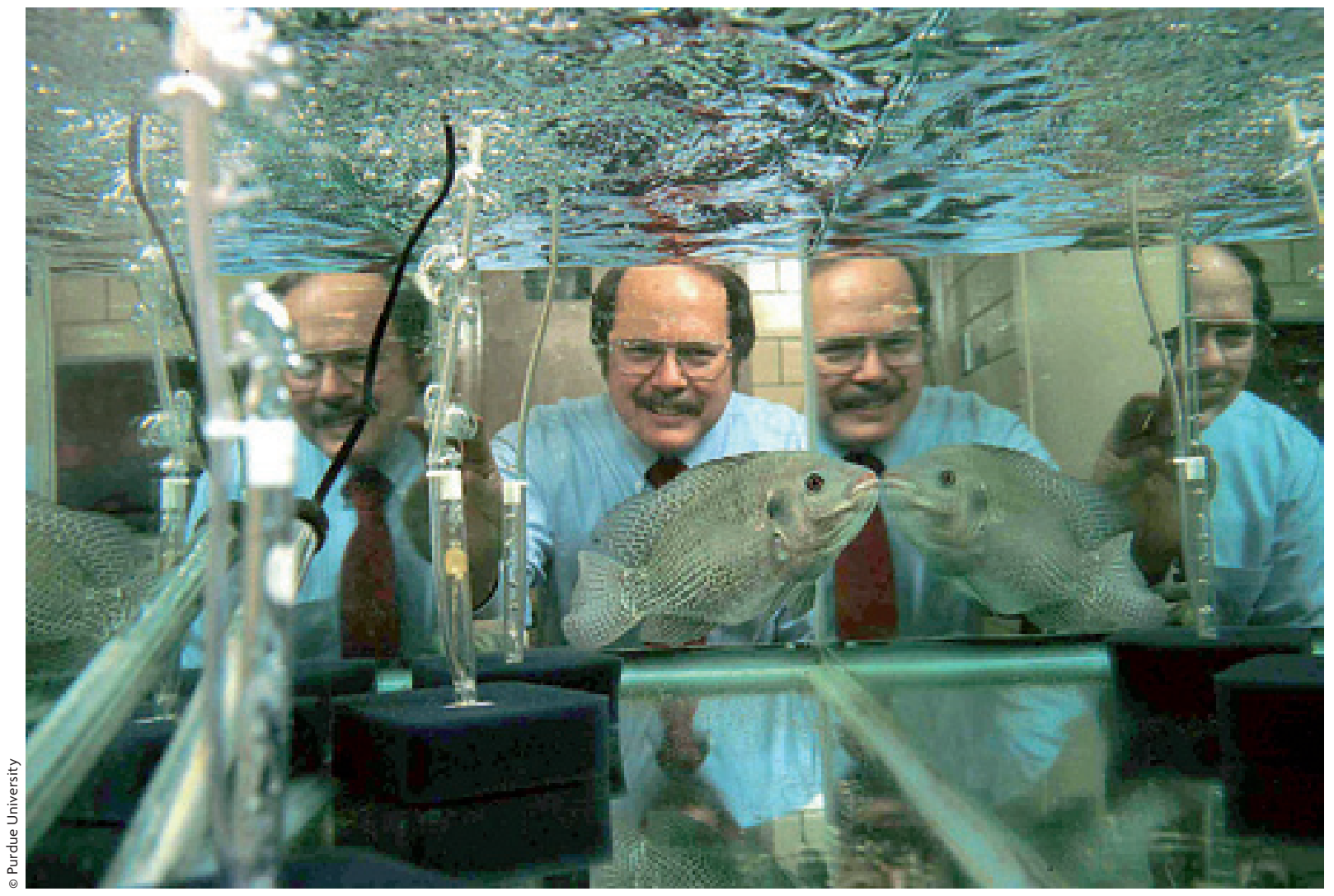

L'investigador William Muir, de la Universitat de Purdue (Indiana, EUA), contemplant el peix medaka transgènic. Els mascles de medaka que són més grossos que la mitjana tenen quatre vegades més èxit en l'aparellament i cria dels seus alevins. Els mascles transgènics medaka, encara més grossos, són fins a set vegades més reeixits en l'aparellament. No obstant això, la descendència té una taxa de supervivència més baixa.

La relació entre millora i evolució ha estat tan estreta que no és possible destriar entre els avenços de la teoria evolutiva que han contribuït als avenços de la millora genètica i viceversa (Toro i Castro, 2009). A vegades, principis àmpliament coneguts de la genètica evolutiva, com, per exemple, la necessitat de variabilitat genètica per a assegurar l'èxit d'una població a llarg termini, s'han posat de manifest, de manera catastròfica, en algunes experiències agronòmiques. A finals dels anys seixanta del segle Xx, més del $85 \%$ de les llavors de dacsa sembrades als EUA eren homozigots per a un gen que suprimeix el desenvolupament de les flors masculines, la qual cosa afavoreix la producció d’híbrids. No obstant això, una conseqüència no prevista de la presència d'aquest factor era l'augment de la susceptibilitat de les plantes a l'atac d'una estirp d'un fong, la qual cosa va ocasionar pèrdues de més de mil milions de dòlars l'any 1970. Per evitar les conseqüències de la pèrdua de variabilitat que acompanya moltes estratègies de millora, es va potenciar la creació de bancs de germoplasma on es conserven varietats i espècies silvestres relacionades amb les estirps comercials, però resistents a malalties i a factors ambientals com ara la salinitat i la sequera.

\section{SELECCIÓ NATURAL I SELECCIÓ SEXUAL}

Una de les forces que poden conduir a una mala adaptació és la selecció sexual. Es tracta d'un cas especial de la selecció natural. La selecció sexual actua sobre la capacitat d'un organisme per a arribar a aparellar-se amb èxit. La fantàstica coloració de l'atractiva cua del paó va portar Darwin a considerar que la presència exclusiva de certs caràcters en els mascles no vol dir que tinguen un valor de supervivència per se (si així fóra, es faria difícil imaginar per què les femelles no en posseeixen), sinó perquè aquests guarniments són atractius i per tant són trets que faciliten l'aparellament. De fet són caràcters indicadors de l'estat de salut i això normalment implica una major 
eficàcia biològica en la descendència. Aquestes idees són rellevants en un entorn pràctic, com va demostrar el ben conegut millorador animal de la Universitat de Purdue a Indiana (EUA) W. Muir juntament amb R. Howard, en experiments duts a terme amb transgènics del peix japonès medaka (Toro, 2011). Van trobar que els mascles de medaka que són més grans que la mitjana tenen quatre vegades més èxit en l'aparellament i cria dels seus alevins. Els mascles transgènics medaka, encara més grossos, són fins a set vegades més reeixits en l'aparellament. No obstant això, també van trobar que la seua descendència tenia una taxa de supervivència més baixa. Utilitzant aquests valors reals en un model de simulació en ordinador, van analitzar el que succeiria en introduir seixanta mascles transgènics medaka en una població natural de 60.000 individus. La femella salvatge de medaka percep el mascle transgènic com el company més atractiu. Però, en aquest cas, les aparences enganyen perquè, per bé que el mascle transgènic és més gros i millor company, la seua descendència mor abans que no la del mascle salvatge, més petit. En tan sols quaranta generacions, el conjunt de l'espècie es veuria abocat a l'extinció. Van encunyar el terme «efecte del gen troià» per descriure el fet que els mascles transgènics medaka amaguen darrere d'una aparença atractiva el gen que pot destruir tota una població.

\section{SELECCIÓ PER A CARÀCTERS SOCIALS}

L'existència de comportaments altruistes planteja un repte a la interpretació neodarwiniana del comportament. Una primera explicació, ja proposada per Darwin, és la selecció entre grups: «No pot haver-hi cap dubte que una tribu que incloga molts membres que posseeixen en alt grau l'esperit de patriotisme, fidelitat, obediència, valor i simpatia, que estan sempre disposats a prestar ajuda als altres i a sacrificar-se pel bé comú, seria victoriosa sobre les altres tribus, i això seria selecció natural.»

Es pot dir que avui dia molts biòlegs evolutius dubten que aquest procés puga ser eficaç i pensen que la selecció natural actua afavorint uns individus sobre altres en compte d'un grup sobre els altres. El mecanisme preferit pels biòlegs evolutius per a explicar l'evolució de l'altruisme és la selecció de parentiu (kin-selection). En un article clàssic publicat el 1964, el llavors jove biòleg britànic W. Hamilton va assenyalar que si un determinat gen indueix una persona a sacrificar la seua vida a canvi de salvar la d'uns quants parents, el nombre de còpies d'aquest gen en les generacions posteriors podria créixer més ràpidament que si el sacrifici no s'haguera fet, ja que els parents tenen una major probabilitat de ser portadors dels mateixos gens que l'individu

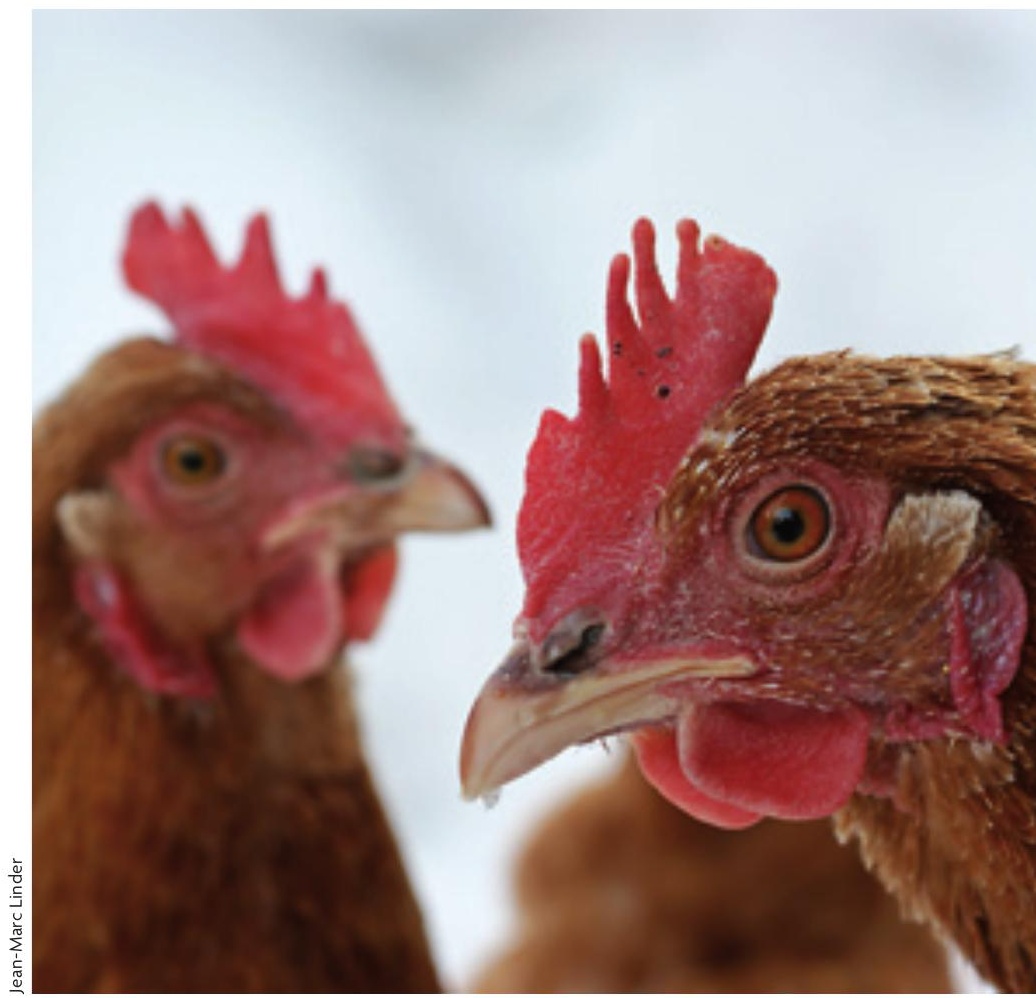

\section{«S'HA DEMOSTRAT QUE PODEN SELECCIONAR-SE PER SELECCIÓ DE GRUPS O SELECCIÓ DE PARENTIU ANIMALS MENYS AGRESSIUS»}

que se sacrifica. És a dir, el comportament altruista és un cost per a l'individu que el realitza, però representa un benefici per a aquells que interactuen amb ell i, si aquests individus són els seus parents, aquest benefici revertirà indirectament en l'altruista.

Hamilton va establir la relació entre el cost atribuït a l'autor de la conducta altruista (c) i el benefici per als seus receptors $(b)$. Aquesta relació es coneix com la regla de Hamilton i s'indica com segueix: un tret es veurà afavorit per la selecció natural si el producte $R b$ és major que $c$, essent $R$ la proporció de gens compartits per l'autor i el receptor (el coeficient de relació additiva en l'argot dels milloradors). El coeficient $R$ és igual a $0,5 \mathrm{si}$ són germans, 0,25 si són mig germans i 0,125 si són cosins. En aquest sentit es comenta que J. B. S. Haldane, un dels fundadors de la síntesi neodarwiniana, va dir en els anys trenta mentre bevia cervesa en un pub que no li importaria arriscar la seua vida si així salvava dos germans o vuit cosins. La idea ja havia estat formulada pel famós millorador d'animals J. L. Lush el 1951: «La 
competència i la selecció entre les famílies podria fer que la selecció afavorira determinats gens que esperonen el seu posseïdor a sacrificar-se pel seu grup, sempre que el sacrifici promoga el benestar biològic dels seus familiars (alguns dels quals tenen part dels seus propis gens) prou per compensar amb escreix els gens perduts en el seu propi sacrifici.»

Just el mateix any de la publicació de l'article de Hamilton i inspirat per aquest, el millorador de plantes australià B. Griffing va proporcionar un enfocament rigorós de la genètica quantitativa de les interaccions entre els individus, incloent-hi la teoria de la resposta a la selecció. Va considerar que el fenotip d'un individu es pot descompondre en un efecte directe del propi individu i un efecte associat com a conseqüència de viure en grup. Per exemple, l'efecte directe en el comportament de picatge canibalístic en gallines mostra la capacitat d'un animal per a sobreviure evitant ser picotejat, mentre que els efectes asso- ciats es refereixen a l'efecte sobre la supervivència del mateix animal del seu comportament de picatge dels altres membres de la seua gàbia. Griffing va ser capaç de derivar les equacions de la resposta a la selecció artificial individual (que pot ser negativa), i la resposta a la selecció de grups i a la selecció familiar, que en aquests dos últims casos sempre és positiva. En essència, és el mateix mecanisme de Hamilton que afavoreix el comportament altruista a través de la selecció natural.

L'evidència en suport de la teoria de Griffing es va obtenir experimentalment durant els anys setanta $\mathrm{amb}$ insectes de laboratori $\mathrm{i}$ amb espècies domèstiques (Wade et al., 2010). Va ser novament el millorador Muir qui en els vuitanta va practicar amb èxit selecció de grups en gallines ponedores obtenint línies de menor mortalitat. També llavors Moav i Wohlfarth van observar en carpes una resposta negativa a la selecció artificial per a creixement que ells van atribuir al fet que indirectament s'estaven seleccionant els peixos més agressius. No obstant

\section{ALTRUISTES PLANTEJA UN}

REPTE A LA INTERPRETACIÓ

NEODARWINIANA DEL COMPORTAMENT"

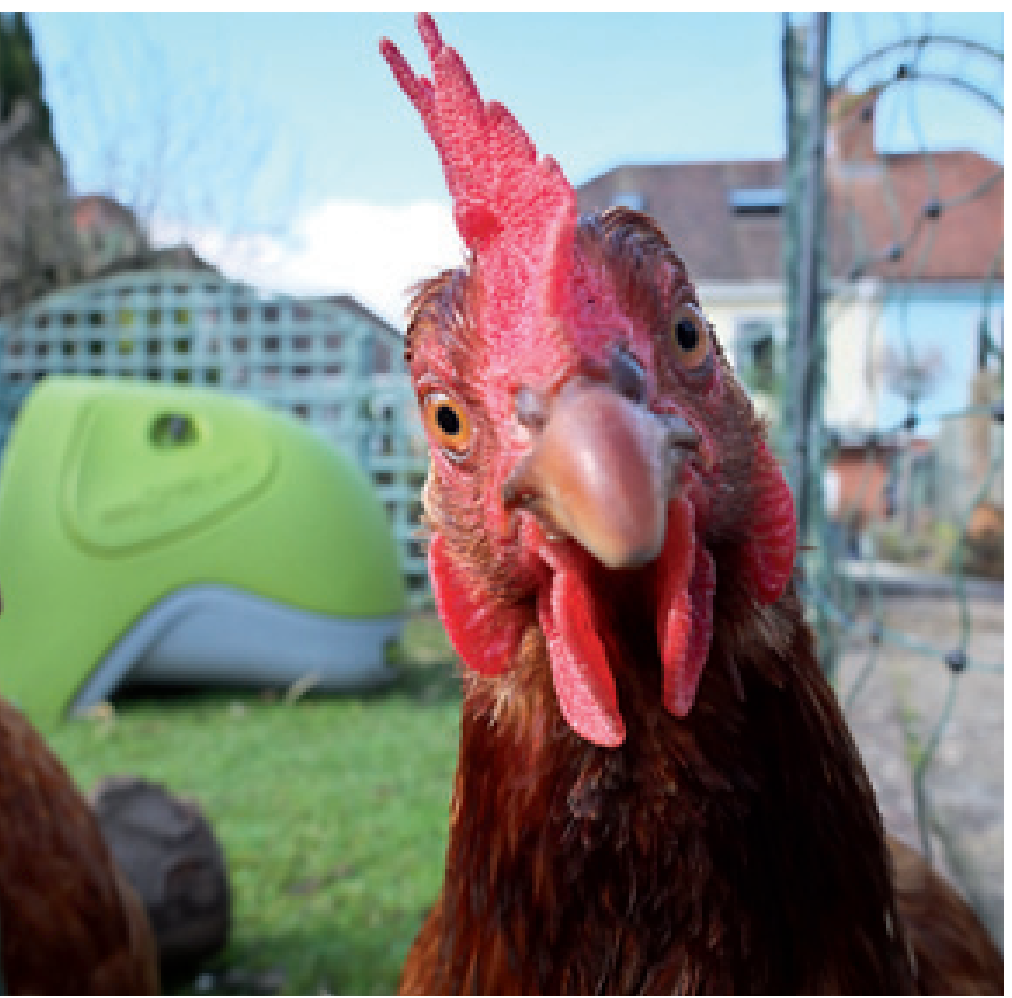

L'efecte directe en el comportament de picatge canibalístic en gallines mostra la capacitat d'un animal per a sobreviure evitant ser picotejat, mentre que els efectes associats es refereixen a l'efecte sobre la supervivència del mateix animal del seu comportament de picatge als altres membres de la seua gàbia. això, quan la selecció mirava de triar les millors famílies (una forma de selecció de parentiu), els resultats van ser positius.

En la millora genètica la importància de considerar aquestes idees creix a la vegada que la normativa referida al benestar animal, que afavoreix la cria en grups (amb major competició), cosa que exigeix seleccionar animals menys agressius. Quan les gallines, per exemple, es crien en grups la mortalitat augmenta com a consequiència del picatge i cal tallar-los el bec per evitar-ho. S'ha demostrat que poden seleccionar-se per selecció de grups o selecció de parentiu animals menys agressius, amb la qual cosa les pèrdues poden reduir-se a la meitat. En resum, es tracta d'una nova aplicació de les idees evolutives que poden contribuir a una producció animal més sostenible i preocupada pel benestar animal.

\section{BIBLIOGRAFIA}

López-Fanjul, C.; Castro, L. i M. A. Toro, 2009. «Darwinismo: aplicaciones y devociones». Revista de libros, 156: 32-39.

Toro, M. A., 2011. «Future Trends in Animal Breeding Due to New Genetic Technologies». Advances in Animal Biosciences, 1: 546-557. DOI: $<10.1017 /$ S2040470010005431>.

TORO, M. A. i L. CASTRO, 2009. «Evolución aplicada: la utilidad del darwinismo». In LóPEZ-FAnuUl, C. [ed.], 2009. El alcance del darwinismo. A los 150 años de «El origen de las especies». Colegio Libre de Eméritos. Madrid. Wade, M. J.; Bijma, P.; Ellen, E. D. i W. Muir, 2010. «Group Selection and Social Evolution in Domestic Animals». Evolutionary Applications, 3 : 453-465. DOI: $<10.1111 / \mathrm{j} .1752-4571.2010 .00147 . x>$.

Miguel Ángel Toro. Catedràtic de Producció Animal de la Universitat Politècnica de Madrid. 